\title{
Appropriate Nitrogen Management: A Tool for Potential Fodder Oat Production - A Review
}

\section{A.V. Dahipahle*, Neha Sharma, Sandeep Kumar, Hari Singh, Sanjeev Kumar Kashyap and Vikramkumar}

\author{
Department of Agronomy, Institute of Agricultural Sciences, Banaras Hindu University, \\ Varanasi-221005, India \\ *Corresponding author
}

\begin{tabular}{|c|c|}
\hline & A B S T R A C T \\
\hline & nclude forage, fodder, straw for bedding, \\
\hline & hay, haylage, silage chaff, human food; most commonly, they are rolled or \\
\hline Fodder, & crushed into oat meal or ground into fine oat flour. The major components \\
\hline $\begin{array}{l}\text { Food, } \\
\text { Nitrogen } \\
\text { management. }\end{array}$ & $\begin{array}{l}\text { of oats that contribute to its function include } \beta \text {-glucan, protein, oil, and } \\
\text { starch. The minor protein of oat is a prolamine. Application of } 100 \text { to } 120\end{array}$ \\
\hline Article Info & $\begin{array}{l}\mathrm{Kg} \mathrm{N} \mathrm{ha}^{-1} \text { recorded significantly higher growth as well as yield attributes } \\
\text { resulting in higher green and dry fodder yield }\left(\mathrm{q} \mathrm{ha}^{-1}\right) \text { as compared to } 80,60\end{array}$ \\
\hline $\begin{array}{l}\text { Accepted: } \\
19 \text { April } 2017 \\
\text { Available Online: } \\
10 \text { May } 2017\end{array}$ & $\begin{array}{l}\text { and } 40 \mathrm{Kg} \mathrm{N} \mathrm{ha}{ }^{-1} \text {. Significantly higher values of Crude Protein, Crude } \\
\text { Fibre, Acid Detergent Fibre, Neutral Detergent Fibre, N, P and K content in } \\
\text { dry fodder and total uptake by oat were recorded due to application of } 100 \\
\mathrm{Kg} \mathrm{N} \mathrm{ha}^{-1} \text {. }\end{array}$ \\
\hline
\end{tabular}

\section{Introduction}

Oat (Avena sativa L.) is one of the most important cultivated fodder crops in the world. Oat is grown in India mainly for its nutritive grain and fodder purpose. It is good balanced feed for cattle, sheep and other domestic animals. Green fodder contain about 10-12 per cent protein and 30-35 per cent dry matter (Hand book of Agriculture, 2007). Under the situation of limited water supply oat can be a good choice as an alternative fodder crop.

At present in India availability of fodder resources is around 60 per cent of the requirement and area under fodder crops is around $8.6 \mathrm{~m}$ ha. Supply and demand scenario of forage and roughages for 1995-2025 also provide the figure of actual deficit as per cent demand for green forage 696 million tons (63.50 per cent) and dry roughages 143 million tons (23.56 per cent) for the year 2015 which is based on Eleventh five year plan document, Government of India (Handbook of Agriculture, 2007). To meet the fodder shortage for the growing animal population, the fodder growing area should ideally be around $20 \mathrm{~m}$ ha by $2020 \mathrm{AD}$, but this appears to be rather difficult to achieve.

Livestock production is the backbone of Indian Agriculture contributing 7 per cent to national GDP and source of employment and 
ultimate livelihood for 70 per cent population in rural areas. India is having the largest livestock population of 520 million heads, which is about 15 per cent of the world's livestock population (Das et al., 2009).

The livestock population is expected to grow at the rate of 0.55 per cent in the coming years and the population is likely to be around 1.70 billion by 2050 . Though India is among the leading producers of milk, meat and eggs, productivity of our animals is $20-60$ per cent lower than the global average due to improper nutrition. Half of the total losses in livestock productivity are contributed to the inadequacy in supply of feed and fodder (DARE/ICAR Annual Report (2012-13).

\section{Uses of oat}

\section{Animal feed}

Oats are grown for use as grain as well as forage and fodder, straw for bedding, hay, haylage, silage and chaff. Oat is an important winter fodder, mostly fed as green but surplus is converted into silage or hay to use during fodder deficit periods (Suttie and Reynolds, 2004). Oat as a forage crop has the advantage of being winter hardy and serves as catch crop (Morey, 1961). It is preferred feed of all animals and its straw is soft and grain is also good feed for dairy cows and young animals. Oat protein is nearly equivalent in quality to soy protein, which has been shown by the World Health Organization to be equal to meat, milk, and egg protein. This is mainly due to improvement in oat hay quality brought about by higher quality standards demanded by the export hay market (Lush, 1945). Inadequate supply of quality feed and fodder is the primary cause of lower productivity of milk in animals of India (Patel et al., 2011). Therefore, to meet the need of animal products and to maintain good health and potential of livestock in terms of milk and meat there is a huge importance of fodder cultivation to compensate the fodder demand during lean period. The present production is not proportionate with the demand.

Deficiency of green fodder will be about $64.9 \%$ and for dry fodders it may go to up to $24.9 \%$ in 2025 A.D (Government of India Planning Commission, 2001). There is an urgent need of exploiting new intervention in research technologies to magnify forage yield in terms of higher yield of green fodder and dry matter per unit area. The forage oat varieties having higher productivity, better quality and tolerance to abiotic stress is the need of the hour in bridging the gap between demand and supply of green fodder.

\section{Cultivation of oat}

Oat grows best in loam to clay loam soil with adequate drainage. They produce satisfactory yields on heavy or light soils with proper moisture. It can be grown under moderate acidic or saline conditions also. A seed rate of $80-100 \mathrm{~kg} / \mathrm{ha}$ is recommended for uniform stand in oats. Low tillering varieties should be sown with 20-25 cm row-to-row spacing while high tillering type should be sown at 30 $\mathrm{cm}$ apart. Sowing of seed should preferably be done in line with seed drill. Sowing time varies from one location to other. Oat is sown in early October to end of November in northwest to east zone of the country. It is recommended to add 15-20 t/ha of FYM at the time of land preparation. Application of $80 \mathrm{~kg} \mathrm{~N}, 40 \mathrm{~kg} \mathrm{P} 2 \mathrm{O} 5 / \mathrm{ha}$ to single cut and 100 $\mathrm{kg} \mathrm{N}, 40 \mathrm{~kg} \mathrm{~K} 2 \mathrm{O} / \mathrm{ha}$ to multicut varieties boost crop growth. In double and multicut varieties, top dressing of $40 \mathrm{~kg} \mathrm{~N} / \mathrm{ha}$ in two equal split after first and second cut should be done, respectively. Oats require 4-5 irrigations including the pre-sowing irrigation. On time irrigation facilitate the tillering vigorously, which leads to huge green forage yield. Cutting of single cut oat cultivars is 
done at 50 per cent flowering. For good regrowth, first cut should be taken at $8-10 \mathrm{~cm}$ above the soil surface.

Although, nitrogen application affects all growth and yield parameters which can be described as following headings-

\section{Effect on growth attributes of crop}

Growth attributes consisting plant height, dry matter accumulation, number of tillers $\mathrm{m}^{-2}$, leaf area etc. Various researchers recorded effect of nitrogen on growth attributes of fodder oats. Bhilare et al., 2008 from G.B. Pant University of Agriculture and Technology, Pantnagar carried out a field experiment to study the response of oat (Avena sativa L.) to nitrogen levels under different cutting management and reported that with increase in levels of nitrogen from 0 to $160 \mathrm{~kg} \mathrm{ha}^{-1}$, significantly increased the plant height $(158.6 \mathrm{~cm})$, number of shoots (46.8 per $0.5 \mathrm{~m}$ row length) and leaves (222.8 per 0.5 meter row length) in variety UPO-212. Whereas, Pathan et al., 2009 a recorded response of nitrogen levels up to $120 \mathrm{~kg} \mathrm{~N}$ in single cut oat genotypes in Rahuri region of Maharashtra and they also observed that increasing nitrogen levels up to $120 \mathrm{kgN} \mathrm{ha}^{-1}$ significantly increased the plant height $(129.70 \mathrm{~cm})$ in variety RO-19and the higher plant population $\left(94.17 \mathrm{~m}^{-2}\right)$ in variety UPO04-01.

Similarly, response of Nitrogen up to $120 \mathrm{~kg}$ $\mathrm{N} \mathrm{ha}{ }^{-1}$ on growth attributes also reported by Roshan et al., 2012 and Dubey et al., 2013. Optimum growth attributes due to proper $\mathrm{N}$ management is responsible good fodder oat yield on unit area basis.

\section{Effect on yield and yield attributes of crop}

Although, oats also used for human food purpose, its nutritive value of grain and grain yield also important for food security.
Purpose of fodder cultivation is important for good nitrogen management. Dose of nitrogen should be based on that purpose. Joon et al., (1995) from Hissar, revealed that application of $80 \mathrm{Kg} \mathrm{N}^{-1}$ recorded higher grain yield (22.5 and $19.5 \mathrm{q} \mathrm{ha}^{-1}$ ) than other nitrogen levels viz., 60, 40 and $20 \mathrm{Kg} \mathrm{N}^{-1}$ and over control. However, application of nitrogen level $80 \mathrm{Kg} \mathrm{ha}^{-1}$ recorded higher straw yield $\left(75.7 \mathrm{q} \mathrm{ha}^{-1}\right)$ which was at par with $60 \mathrm{~kg} \mathrm{~N}$ $\mathrm{ha}^{-1}$. Besides nitrogen management, another essential major nutrient element i.e. phosphorus is also important for good yield.

Patel et al., (1998) from College of Veterinary Science and Animal Husbandry, Anjora (MP) conducted an experiment on effects of nitrogen and phosphorus on growth and forage yield of oat and reported that the application of nitrogen at $75 \mathrm{~kg} \mathrm{ha}^{-1}$ recorded highest green forage yield and dry matter yield than 50, $25 \mathrm{~kg} \mathrm{~N}^{-1}$ and over control. Cultivation of multi-cut oats should be more emphasized for green fodder yield. Multi-cut oats requires more nitrogen than single cut for better fodder yield. Kumar et al., (2001) conducted a field experiment at Rajasthan Agriculture University, Rajasthan to find out the effect of nitrogen levels and cutting management on yield and quality of different varieties of oat and recorded response of single cut oat variety only up to $120 \mathrm{~kg} \mathrm{~N}^{-}$ ${ }^{1}$ for the yield of green forage (411.6 $\mathrm{q} \mathrm{ha}^{-1}$ ) and dry matter yield $\left(79.1 \mathrm{q} \mathrm{ha}^{-1}\right)$ of oat than two cut system.

However, dose of nitrogen for higher yield varied according to locations which might be evaluated by public sector and government institutions. Different researchers reported different doses of nitrogen at various locations clearly indicated that optimum dose of nitrogen is varied according to locations (Table 4). Thus, location specific research is much needed for better growth and yield of fodder oats. 
Effect on quality and nutrient uptake of crop

Besides good yield of fodder oats, quality is also a major attributes for better livestock health and milk as well as meat yield. Protein is important for quality and quantity point of view milk yield. Dubey et al., (2013) conducted a field experiment at Jawaharlal Nehru Krishi Vishwa Vidyalaya, Jabalpur, (M.P) and reported that, increased levels of nitrogen up to $120 \mathrm{~kg} \mathrm{~N} \mathrm{ha}{ }^{-1}$ produced significantly higher crude protein yield $(9.38$ $\mathrm{kg} \mathrm{ha}^{-1}$ ) Jehangir et al., (2013) also reported similar results. Thus, crude protein yield is mainly concern of suitable nitrogen dose.

Table.1 Top ten oats producers in 2013 (Thousand metric tons)

\begin{tabular}{|l|c|}
\hline European Union & 7,581 \\
\hline Russia & 4,027 \\
\hline Canada & 2,680 \\
\hline Australia & 1,050 \\
\hline United States & 929 \\
\hline Ukraine & 630 \\
\hline Belarus & 600 \\
\hline China & 580 \\
\hline Chile & 560 \\
\hline Argentina & 400 \\
\hline World Total & 20,732 \\
\hline
\end{tabular}

Source: United States Department of Agriculture (2013)

Table.2 Response of fodder oat (in term of green fodder yield ha ${ }^{-1}$ ) with dose of nitrogen

\begin{tabular}{llcl}
\hline Sr. No. & Location & $\begin{array}{c}\text { Response of N dose } \\
\left(\mathrm{kg} \mathrm{ha}^{-1}\right)\end{array}$ & References \\
\hline 1. & Dapoli & 80 & Mahale et al., 2003 \\
2. & Pantnagar & 107 & Bhilare et al., 2008 \\
3. & Rahuri & 120 & Pathan et al., 2014 \\
4. & Jabalpur & 120 & Jha et al., 2012 \\
5. & Jabalpur & 120 & Dubey et al., 2013 \\
\hline
\end{tabular}

There are various evidences that clearly indicated that suitable dose of nitrogen not only increases crude protein yield but content also. Bhilare et al., (2007) reported the crude protein content (19.51\%), Acid Detergent Fibre (49.21 $\%)$, Neutral Detergent Fibre $(60.32 \%)$ and hemicellulose contents $(22.64 \%)$ were significantly higher with increased level of nitrogen up to $160 \mathrm{~kg} \mathrm{~N} \mathrm{ha}^{-1}$. Bhat et al., (2000) also reported the total nitrogen $\left(110.3 \mathrm{~kg} \mathrm{ha}^{-1}\right)$, phosphorus (10.6 $\left.\mathrm{kg} \mathrm{ha}^{-1}\right)$ and potassium (213.2 $\mathrm{kg} \mathrm{ha}^{-1}$ ) uptake by oat was higher at application of $150 \mathrm{~kg} \mathrm{ha}^{-1}$ followed 120 and $90 \mathrm{~kg} \mathrm{~N} \mathrm{ha}^{-1}$. Other evidence reported by Jehangir et al., (2013) revealed that, green and dry fodder yields, crude protein content $(19.50 \%)$ and crude fiber content $(22.31 \%)$ increased with increase in fertility level up to $150 \mathrm{~kg} \mathrm{~N} \mathrm{ha}^{-1}$.

However, cutting management on same nitrogen dose also affects quality parameters. It has been reported that crude protein yield was higher in single cut $\left(7.0 \mathrm{q} \mathrm{ha}^{-1}\right)$ than in two cut system $\left(6.5 \mathrm{q} \mathrm{ha}^{-1}\right)$ while crude protein yield 
increased up to application of $120 \mathrm{~kg} \mathrm{~N} \mathrm{ha}^{-1}$ in both system (Kumar et al., 2001).

\section{Effect on Economics}

Economics of oat cultivation as green fodder found ruminative over various locations according that nitrogen dose have to be evaluated. Gross return, net return and $\mathrm{B}: \mathrm{C}$ ratio affected by nitrogen reported (Luikham et al., 2012). Dubey et al., (2013) reported that increased rate of nitrogen up to $120 \mathrm{~kg} \mathrm{~N} \mathrm{ha}^{-1}$ markedly increased the profitability in terms of B: C ratio (2.50). Similarly, Devi et al., 2014 from Hissar also reported ruminative economics up to $120 \mathrm{~kg} \mathrm{~N} \mathrm{ha}^{-1}$. Integrated nitrogen management found more ruminative with lower dose of nitrogen i.e. $80 \mathrm{~kg} \mathrm{~N} \mathrm{ha}^{-1}$ remaining can be substituted by FYM and biofertilizers. Singh et al., (2005) atPantnagar reported that, the application of nitrogen up to $80 \mathrm{~kg} \mathrm{ha}^{-1}$ along with seed inoculation with azatobactor as well as addition of FYM @ $5 \mathrm{tha}^{-1}$ and taking of two cuts at 55 and 75 DAS proved beneficial to obtain the highest net returns of Rs. 13,360 haand $\mathrm{B}$ : $\mathrm{C}$ ratio of 2.07 .

In conclusion, appropriate amount of nitrogen is essential for harvesting bumper good quality green fodder yield of oat. For better yield 80 to $120 \mathrm{~kg} \mathrm{~N} \mathrm{ha}^{-1}$ must be needed for better growth, yield and quality of fodder oat. However, site specific nitrogen management research should be carried out for further exploration of the yield.

\section{References}

Czerwiński J, Bartnikowska E, Leontowicz H (2004). Oat (Avena sativa L.) and amaranth (Amaranthus hypochondriacus) meals positively affect plasma lipid profile in rats fed cholesterol-containing diets. J. Nutr. Biochem. 15:622-629.

Bhat, M.D., Singh, K.N., Bali, A and Shah, M.H. 2000. Grain yield of oat (Avena sativa L.) as influenced by sowing time and nitrogen levels under temperate conditions of Kashmir.Indian J. Agron. 45(1): 199 - 204.
Bhilare, R.L. and Joshi, Y.P. 2007. Productivity and quality of oat in relation to cutting management and nitrogen levels. Indian J. Agron.52 (3): 247-250.

Bhilare, R.L. and Joshi, Y.P. 2008. Response of oat (Avena sativa L.) to nitrogen levels under different cutting management. $J$. Maharashtra agric Univ. 33 (3): 312-314.

DARE/ICAR ANNUAL REPORT 2012-13. Livestock Management pp. 55-57

Das, N., Misra, A.K., Maity, S.B., Singh, K.K. and Das, M.M. 2009. Forage for sustainable livestock production. Satish Serial Publishing House, Azadpur, Delhi-33. pp. $\mathrm{V}$.

Dubey, A.,Rathi, G.S. and sahu, R. 2013.Effect of nitrogen levels ongreen fodder yield of oat (Avena sativa L.) varieties.Forage Res. 39 (1): 39-41.

Esposito F, Arlotti G, Bonifati AM 2005. Antioxidant activity and dietary fibre in durum wheat bran by-products. Food Res. Int. 38:1167-1173. http://dx.doi.org/10.1016/j.foodres.2005.05. 002

Govt of India, Planning Commission. (2001).

Handbook of Agriculture 2007. Forage Crops and Grasses pp. 1354-1357

Jat, H., Kaushik, M.K., Tiwari, R.C. and Sharma, M. 2015.Growth, yield of fodder oat (Avena sativa. L.) and available soil nitrogen as influenced by irrigation and nitrogen Management.Forage Res.,41 (2): 135-136.

Jehangir, I.A., Khan H. U., Khan, M.H., F. UrRasool, Bhat, R.A., Mubarak, T., Bhat, M. A. and Rasool, S. 2013 Effect of sowing dates, fertility levels and cutting managements on growth, yield and quality of oats (Avena sativa L.) Afr. J. Agric. Res. 8(7): 648-651

Jha, A.K., Shrivastava, A., Raghuvanshi, N.S. andSharma J.K. 2012. Relative performance of new single cut oat genotypes to different nitrogen levels under agro-climatic condition of Kymore plateau zone of Madhya Pradesh. JNKVV Res J46(1): 44-46

Kerckhoffs D, Hornstea G, Mensink R 2003. Cholesterol lowering effect of beta-glucan from oat bran in mildly hypercholesterolemic subjects may 
decrease when beta-glucan is in corporated into bread and cookies. Am. J. Clin. Nutr. 78:221-227. PMid:12885701

Kumar, A., Jaiswal, R.S., Verma, M.L. and Joshi, Y.P. 2001. Effect of nitrogen level and cutting management on yield and quality of different varieties of oat fodder. Indian $J$. AnimNutr. 18 (3): 262-266.

Lasztity R 1999. General characterization of the chemical composition of cereal grains. The structure of the cereal grain. In cereal chemistry, AkademiaiKiado. Budapest, pp. 13-24.

Lush JL 1945. Animal Breeding Plans.3rd edition. Iowa State University Press, Ames Iowa, pp.125-138.

Luikham, E., Kamei, S and Mariam anal, P. S.2012. Yield, quality and economics of oat fodder (Avena sativa. L.) as influenced by nitrogen and varieties.Forage Res., 38 (2): 112-114.

Mahale, B.B., Nevase, V.B. and Thorat, S.T. 2004. Effect of cutting management and nitrogen levels on forage yield of oat. $J$. Soil Crop. 14 (2): 469-472.

Mattila P, Pihlava JM, Hellstrom J 2005. Contents of phenolic acids, alkyl- and alkenylresorcinols, and avenanthramides in commercial grain products. J. Agric. Food Chem. 53:8290-8295. http://dx.doi.org/10.1021/jf051437z; PMid:16218677

Nawaz, N., Abdul R., Zulifakar A., Sarwar, G. and Yousuf, M. 2004. Performance of different oat varieties under the Agroclimatic conditions of Bahawalpur, Pakistan. International J. Agriculture and Biology. 4 (6): 624-626.

Patel, J.R and Rajgopal, S. 1998. Effects of nitrogen and phosphorus on growth and forage yield of oat. J. Maharashtra agric Univ.23 (3): 323-324.
Patel TU, Arvadia MK, Malik PK, Patel DD, Patel PS 2011. Production of oats (AvenaSativa.L) under different cutting management and split application of nitrogen. Indian Journal of Agronamy, 56:164-167.

Pathan, S.H., Gethe, R.M., Manjare, M.R. and Kadlag, A.D. 2005. Response of multicut oat to spacing and nitrogen for green forage yield. Forage Res. 31 (2): 150-151.

Pathan, S.H. and Bhilare, R.L. 2009. Response of nitrogen levels to single cut oat genotypes. J. Maharashtra agric Univ. 34 (3): 333334.

Roshan, P.K., Naik, K.R. and Nayak, Siddarth. 2012.Response of promising varieties of single cut forage oat to different nitrogen levels under agroclimatic conditions of Kymore plateau zone, Madhya Pradesh.JNKVV Res J.46 (1): 59-61.

Singh, S.D., Dubey, S.V., Agrawal, S.B. and Rawat, A. 2005. Effect of organic and inorganic sources of nitrogen on yield and quality of fodder oat under different cutting systems. JNKVV Research J. 39 (2): 12-15.

Van Soest, P.J., Robertson, J.B. and Lewis B.A. 1991. Methods for dietary fiber, neutral detergent fiber, and non starch polysaccharides in relation to animal nutrition. J. Dairy Sci., 74. 3583-3597.

Welch RW 1995. The Oat Crop: Production and Utilization. ed. Chapman and Hall, UK. P. 584. http://dx.doi.org/ 10.1007/978-94-0110015-1

Wilkins, P.W., Allen, D.K. and Mytton, L.R. 2000. Differences in the nitrogen use efficiency of perennial rye grass varieties under simulated rotational grazing and their effects on nitrogen recovery and herbage nitrogen content. Grass and Forage Science 55: 69-76

\section{How to cite this article:}

Dahipahle, A.V., Neha Sharma, Sandeep Kumar, Hari Singh, Sanjeev Kumar Kashyap and Vikramkumar. 2017. Appropriate Nitrogen Management: A Tool for Potential Fodder Oat Production A Review. Int.J.Curr.Microbiol.App.Sci. 6(5): 1860-1865. doi: https://doi.org/10.20546/ijcmas.2017.605.204 